\title{
The Duration Of Relationship Banking And The Performance Of Tunisian Firms: An Empirical Test
}

Abdelaziz Hakimi, FSJEG Jendouba \& University of Sousse, Tunisia Helmi Hamdi, CERGAM (4225), Aix-Marseille University, France

\begin{abstract}
In this paper, we examine whether there exist a linkage between the duration of a bank enterprise relationship and the performance of Tunisian firms. To this end, we collected data of 100 Tunisian companies for the period 2000-2007. By, applying panel data technique, our results reveal that the cost of credit decrease the performance of Tunisian firms while the duration of bank relationships improves their performance and increase their profitability.
\end{abstract}

Keywords: Bank Relationships; Duration; Tunisia; Panel Data

\section{INTRODUCTION}<smiles>[C]1C=CCCC=C1</smiles>

ince the past few years, the relationship between banks and enterprises has received a great deal of attention by scholars and policymakers. This is mainly due to the interdependency between the two institutions and their growing role in economy. In fact, banks are the principal channel of financing firms and firms have become one of the major engines of economic development through creation of employment. Given their importance and their weight in economy, the bank-enterprise relationships should be efficient to ensure stability of the economic system as a whole as the failure of the former or the later could generate imbalances (Hamdi et al., 2012a,b).

In modern literature, several theoretical and empirical studies focused on the nature of bank relationships (determinants of the relationships, costs and availability of credits, etc) whereas few studies investigated the duration of the two institutions. The duration of the lending contract constitutes one of the principal components of the bankenterprise relationships as it can influence the negotiation of credit conditions and hence the performance of the firms. Recently, a great attention has been devoted to this issue to understand why some firms maintain a longer relationship with the current lender while some others prefer a shorter duration ${ }^{1}$. Literature provides conflicting results. In fact, some studies show that during financial instability, the long duration allows enterprises to benefit from competitive interest rates and high degree of availability of credits. Berger and Udell (1995), Blackwell and Winters (1997) and Bodenhorn (2003) find that longer duration impacts reduces loan rates for American' SMEs. Harhoff and Körting (1998) and Eber (2001) show that a long duration reduces the problem of asymmetry of information. The repetitive transactions during the time allow the two parts to collect the maximum of required information which in turn will reduce the problem of the credit rationing. In the same way of analysis, the studies of Peterson and Rajan (1994), Angelini et al. (1998) show that the long term relations support the availability of credit at a lower cost.

In the other hand, some studies reveal the negative consequences of maintaining a long duration with the lenders. In general, banks evaluate their clients (enterprises) and grant them credits on the base of their past financial

\footnotetext{
${ }^{1}$ We recall that the duration of bank-enterprise relationship changes from one banking system to another (Hamdi et al., 2012b). For example, the average duration of banking relationship in Germany is twenty years (Elsas \& Krahnen, 1998) while it is fourteen years in Italy (Angelini, Di Salvo \& Ferri, 1998) and it varies between twenty-one and thirty years in Japan (Horiuchi, Parker \& Fakuda, 1998). In the United States it is around seven years (Petersen \& Rajan, 1995, Blackwell \& Winters, 1997; Cole, 1998) and it is about nine years in Finland (Peltoniemi, 2007).
} 
results. Some firms, despite their good current position, may suffer from credit rationing because they had bad results in the past. In this case, access to finance became unaffordable and this may hamper the investment activities of the firms. Long term relationship also allows banks to get private information to their clients and this may make fragile their relationship. Sharpe (1990) and Rajan (1992), opine that longer lending relationships can be nonoptimal because banks can have monopoly information with regard to future credit distribution. Another concern rising from long duration is the hold-up problem (Greenbaum et al., 1989; Sharpe, 1990; Rajan, 1992; Von Thadden, 1998). During the time, the lending relationships generate a lock-in problem given that banks will have the monopoly power over the customer. In same line of analysis, when the duration of the lending contract lengthens, banks endogenously gain an information monopoly and are able to extract additional rents from their clients. Those problems may generate some costs for the borrowing firms which usually affect the credit amount and loan covenants.

Following this development, we distinguish an ambiguity according to the advantages and disadvantages from each type of relationship (short and long). So the performance of the firms can be influenced by the benefits and the costs of the duration of relationship banking. The aim of this paper is to test empirically the effect of the duration of bank relationships (long term) on the performance of the Tunisian' SMEs. Our sample is based on 100 firms observed during the period 2000-2007. The empirical study is based on panel data analysis with fixed effect regression. Our results reveal that the cost of credit decrease the performance of Tunisian firms while the duration of bank relationships improves their performance and increase their profitability.

The remainder of the paper is as follows. Section 2 presents data and methodology; Section 3 provides empirical results and finally Section 4 concludes.

\section{METHODOLOGY}

Our study is based on data collected from 100 Tunisian companies of different size and operating in various sectors for the period 2000-2007. For the quantitative variables we use the financial statements of these firms such as balance sheets and income statements. Regarding qualitative data, they were obtained following a distribution of a questionnaire ${ }^{2}$. The performance of the firms is measured by the return on equity (ROE) and the return on assets (ROA). The estimation method is based on panel data technique and the econometric equation is written as follows:

$$
\begin{aligned}
& \mathrm{ROA}_{i, t}=\alpha_{0}+\beta_{1} \operatorname{SIZE}_{i, t}+\beta_{2} A G E_{i t}+\beta_{3} \mathrm{SECT}_{i, t}+\beta_{4} \operatorname{COST}_{i, t}+\beta_{5} R A T_{i, t}+\beta_{6} M L T P L_{i, t}+\beta_{7} N B A N K_{i, t}+\beta_{8} D U R_{i, t}+\varepsilon_{i} \\
& \mathrm{ROE}_{i, t}=\alpha_{0}+\beta_{1} \operatorname{SIZE}_{i, t}+\beta_{2} A G E_{i, t}+\beta_{3} S E C T_{i, t}+\beta_{4} \operatorname{COST}_{i, t}+\beta_{5} R A T_{i, t}+\beta_{6} M L T P L_{i, t}+\beta_{7} N B A N K_{i, t}+\beta_{8} D U R_{i, t}+\varepsilon_{i}
\end{aligned}
$$

where: ROA and ROE: measure the performance of the firms; DUR: is the duration of bank relationships measured by the number of years the both parties are partners, COST refers to the cost of credit; Age is the age of the firm (date of creation to the date of the collected data), SIZE is the size of the firm measured by the natural logarithm of total assets, $M L T P L$ is a dummy variable reflecting the multiplicity of relationships, it takes 1 if the company is financed by more than one bank and 0 otherwise, NBank is the number of banks financing the company, RAT is a dummy variable of credit rationing it takes the value of 1 if the amount of future credit granted is constant or has increased and 0 if the amount of credit decreases. Finally, SECT is a dummy variable reflecting the sector of activity; it takes the value of 1 if the firm operates in the industry and 2 otherwise.

In the empirical analysis, we suggest to test the two following hypotheses:

H1: The duration of the banking relationship improves the performance of Tunisian firms.

H2: The duration of the banking relationship deteriorates the performance of Tunisian firms.

\section{RESULTS}

According to Table 1 below, the average return on assets is $2.81 \%$ and the average return on equity is $5.13 \%$. Companies built their bank relationships that last 8.97 years on average. The number of bank relationships

\footnotetext{
${ }^{2}$ Questionnaire was send to 187 firms, only 100 of them have responded (53.47\%). Sectors include manufacturing, service and trade only.
} 
varies between one and two (1.74). This low number of bank partners is associated with an average of $41.10 \%$ of multiple banking. The average age of this sample is 9 years and the average cost of credit for these companies is $8.3 \%$ with a minimum of $5.75 \%$ and a maximum of $11.8 \%$.

Table 1: Descriptives Statistics

\begin{tabular}{lcccccccccc}
\hline Variables & Roa & Roe & Dur & Mltpl & Nbank & Size & age & Sect & Rat & Cost \\
\hline Mean & 0.0281 & 0.0513 & 8.97 & 0.411 & 1.74 & 0.965 & 9.045 & 0.5875 & 0.231 & 0.083 \\
Mini. & 0.0051 & 0.0245 & 0 & 0 & 1 & -0.1815 & 0 & 0 & 0 & 0.0575 \\
Max. & 0.05 & 0.075 & 26 & 4 & 1 & 2.185 & 26 & 1 & 1 & 0.118 \\
N. of bs. & 800 & 800 & 800 & 800 & 800 & 800 & 800 & 800 & 800 & 800 \\
\hline
\end{tabular}

Table 2 below illustrates the degree of correlation between the different variables of the study. This matrix shows that the correlation between different variables is very low ${ }^{3}$; implying the absence of multicollinearity between different variables of our estimation.

Table 2: The Correlation Matrix

\begin{tabular}{|c|c|c|c|c|c|c|c|c|c|c|}
\hline & Roa & Roe & Dur & Mltpl & Nbank & Size & Age & Sect & Rat & Cost \\
\hline Roa & 1 & & & & & & & & & \\
\hline Roe & 0.678 & 1 & & & & & & & & \\
\hline Dur & 0.028 & 0.0042 & 1 & & & & & & & \\
\hline Mltpl & -0.026 & -0.0244 & 0.1013 & 1 & & & & & & \\
\hline Nbank & -0.027 & -0.0181 & 0.0612 & 0.1675 & 1 & & & & & \\
\hline Size & 0.487 & 0.3340 & 0.0059 & 0.2531 & 0.2462 & 1 & & & & \\
\hline Age & 0.031 & 0.0063 & 0.3874 & 0.0877 & 0.0494 & 0.0047 & 1 & & & \\
\hline Sect & -0.037 & -0.0457 & 0.0488 & -0.073 & -0.102 & -0.177 & 0.0233 & 1 & & \\
\hline Rat & -0.045 & -0.0616 & -0.1028 & -0.229 & -0.213 & -0.076 & -0.097 & 0.0019 & 1 & \\
\hline Cost & -0.025 & -0.0221 & -0.3919 & -0.009 & 0.0194 & 0.0432 & -0.390 & 0.0008 & 0.0242 & 1 \\
\hline
\end{tabular}

The results of various tests are provided in Table 3 below. The Chow test is significant; in addition, the Breush Pagan (LM) statistic test and the Hausman test are significant at 1\%. According to Hausman test statistics we apply the fixed effects specification for the model.

Table 3: Results of the Fixed Effect Estimation

\begin{tabular}{|c|c|c|c|c|}
\hline \multirow[t]{2}{*}{ Explanatory Variables } & \multicolumn{2}{|c|}{$\begin{array}{c}\text { Model 1 } \\
\text { (Return on Assets = ROA), (FE) }\end{array}$} & \multicolumn{2}{|c|}{$\begin{array}{c}\text { Model 2 } \\
\text { (Return on Equity = ROE), (FE) }\end{array}$} \\
\hline & Coefficients & (z-statistic) & Coefficients & (z-statistic) \\
\hline Dur & $\begin{array}{c}0.0001 * * * \\
(0.000)\end{array}$ & 8.12 & $\begin{array}{c}0.0012 * * * \\
(0.000)\end{array}$ & 2.61 \\
\hline Mltpl & $\begin{array}{l}-0.0007 \\
(0.244)\end{array}$ & -1.17 & $\begin{array}{l}-0.0003 * * * \\
(0.000)\end{array}$ & -3.26 \\
\hline Nbank & $\begin{array}{c}-0.0005^{*} \\
(0.089)\end{array}$ & -1.73 & $\begin{array}{r}-0.0005 \\
(0.425)\end{array}$ & -0.80 \\
\hline Size & $\begin{array}{l}0.0116 * * * \\
\quad(0.000)\end{array}$ & 33.58 & $\begin{array}{l}0.0115 * * * \\
(0.000)\end{array}$ & 16.50 \\
\hline Age & $\begin{array}{l}0.0002 * * * \\
(0.000)\end{array}$ & 9.21 & $\begin{array}{l}0.0008 \\
(0.66)\end{array}$ & 0.44 \\
\hline Sect & $\begin{array}{c}-0.00005 \\
(0.972)\end{array}$ & -0.03 & $\begin{array}{l}-0.0010 \\
(0.725)\end{array}$ & -0.35 \\
\hline Rat & $\begin{array}{r}-0.0004 \\
(0.268)\end{array}$ & -1.11 & $\begin{array}{c}-0.0006 * \\
(0.089)\end{array}$ & -.179 \\
\hline Cost & $\begin{array}{l}-0.0400 * * \\
(0.025)\end{array}$ & -2.25 & $\begin{array}{l}-0.052 \\
(0.149)\end{array}$ & -1.44 \\
\hline $\begin{array}{l}\mathrm{R}^{2} \mathrm{~W} \\
\mathrm{R}^{2} \mathrm{~b}\end{array}$ & \multicolumn{2}{|c|}{$\begin{array}{l}0.6271 \\
0.0505\end{array}$} & \multicolumn{2}{|c|}{$\begin{array}{l}0.2904 \\
0.0154\end{array}$} \\
\hline
\end{tabular}

${ }^{3}$ Except for Size/ROA and Age/DUR. 
Table 3 cont.

\begin{tabular}{lcc}
\hline Fisher Test & $12.35 * * *$ & 9.89 \\
Prob > F & $(0.000)$ & $(0.000)$ \\
Hausman & $1401.29 * * *$ & $137.05^{* * *}$ \\
Prob>chi2 & $(0.000)$ & $(0.000)$ \\
Breusch-Pagan (LM) & $91.07 * * *$ & $28.01^{* * *}$ \\
Prob > chi2 & $(0.0000)$ & $(0.000)$ \\
Number of observations & 800 & 800 \\
\hline
\end{tabular}

The results show that the duration, the age and the size have a positive and a significant correlation with the firm's performance indicators (ROA and ROE). The variables NBank and Cost act negatively and significantly while the variables MLTPL, RAT and SECT are negative and not significant.

The Firm's performance ${ }^{4}$ is positively and significantly correlated with the age of the firm at the $1 \%$ level of significance. This means that the older the companies are, the more their market share increases and the more their performance get better. The average age of companies in our sample varies between 9 and 10 years. This period allows firms to have more experience in negotiating the credit conditions and strengthen their position in the market. The oldest firms control better the market in which they take place and increase their market share and improve their performance.

The size has a significant and a positive effect on the performance. Broadly, large enterprises are often more efficient than small and medium size enterprises (SMEs). This is due to their position in the market and their ability to give the necessary guarantees in obtaining credit (Mitchell \& Rajan, 1994). However, this conclusion seems to be in contradiction with our finding since most companies of our sample are SMEs. This leads us to conclude that despite the small size of firms, results indicate a positive and a significant relationship between the firm's size and the performance. Regarding the variables reflecting the sector (SECT) and the credit rationing (RAT), their effects are not significant.

According to the results, only the variable "Cost" affects negatively and significantly the performance of the Tunisian firms. This means that the cost of credit decreases the performance. This negative relationship is justified by the importance of financial charges during the contract. Generally speaking, small companies suffer from high financing costs because of the lack of experience and reputation. Banks do not trust on start-up, they apply a high interest rate which may enhance the cost of credit and consequently decrease the performance of the firms (Degryse \& Van Cayseele, 2000). The duration of the bank-enterprise relationship becomes a sine qua none condition allowing firms to access to finance at low costs and consequently contributes to increase their welfare.

In conclusion, we can opine that the cost of credit decreases the performance of Tunisian firms while the size, age and duration of banking relationship improve the profitability. These results allow us to accept the hypothesis $\mathrm{H}_{1}$ : the duration of the bank relationship improves the firm's performance.

\section{CONCLUSION}

The lack of extensive theoretical and empirical literature analyzing the duration of the bank lending contract and its effects on the performance of firms motivate us to investigate the nature of this relationship for the Tunisian context. Our sample cover 100 companies observed over the period 2000-2007. We used an econometric model based on panel data with fixed effect regression. Our results showed positive and significant correlation between the duration, the age and the size with the performance of the firms (ROA). The Variables NBANK and COST act in a negative and significant way whereas the effects of variables MLTPL, RAT and SECT are not significant. As for the effects of the duration DUR on the performance of the companies, our results show a positive and a significant correlation. The number of banks exerts a negative and a significant effect on the firm performance (ROA) whereas it has a positive and a non-significant consequence if we retain ROE as the measure of financial

\footnotetext{
${ }^{4}$ In the rest of the paper we will analyze only the ROA as a measure of performance and profitability because it provides more meaningful results.
} 
profitability. The low number of bank relationships ${ }^{5}$ of the Tunisian companies and the orientation towards the exclusive and long term relationship support their performances and improve their profitability. To conclude, we opine that the main benefits of the long term relationship for Tunisian firms are the guaranty of the good conditions of credit in terms of costs and availability and the improvement of their performance.

\section{AUTHOR INFORMATION}

Hakimi Abdelaziz, FSJEG Jendouba. Tunisia. E-mail: abdelazizhakimi@yahoo.fr

Helmi Hamdi, Aix-Marseille Universite CERGAM (4225). E-mail: helmi_aix@yahoo.fr (Corresponding author)

\section{REFERENCES}

1. Angelini, P., Di Salvo, R., \& Ferri, G. (1998). Availability and cost of credit for small businesses: Customer relationships and credit co-operatives. Journal of Banking Finance, 22, 925-954.

2. Berger, A. N., \& Udell, G. F. (1995). Relationship lending and lines of credit in small firm finance. Journal of Business, 68, 351-382.

3. Blackwell, D. W., \& Winters, D.B. (1997). Banking relationships and the effect of monitoring on loan pricing. Journal of Financial Research, 20(2), 275-289.

4. Boderhorn, H. (2003). Short-term loans and long term relationships: Relationship lending in early america. Journal of Money, Credit and Banking, 35(1), 485-504.

5. Cole, R.A. (1998). The importance of relationships to the availability of credit. Journal of Banking and Finance, 22, 959-977.

6. Degryse, H., \& Van Cayseele, P. (2000). Relationship lending within a bank-based system: Evidence from European small business data. Journal of Financial Intermediation, 9(1), 90-109.

7. Detragiache, G., \& Guiso. (2000). Multiple versus single banking relationship: Theory and evidence. Journal of Finance, 55(3), 1133-1161.

8. Eber. N. (2001). Les relations bancaires de long terme : une revue de la littérature. Revue d'Économie politique, 111(2), 195-246.

9. Elsas, R., \& Krahnen, J. (1998). Is relationship lending special? Evidence from credit-file data in Germany. Journal of Banking and Finance, 22(10), 1283-1316.

10. Greenbaum, S. I., Kanatas, G., \& Venezia, I. (1989). Equilibrium loan pricing under the bank-Client relationship. Journal of Banking and Finance, 13, 221-235.

11. Hamdi, H., Hakimi, A., \& Djelassi, M. (2012a). The relationship between costs and availability of credit: an empirical study for some Tunisian firms. Journal of Applied Business Research, 28(3), 515-526.

12. Hamdi, H., Hakimi, A., \& Djelassi, M. (2012b). What dertmines the duration of the bank enterprise relationsip for Tunisian firms. Journal of Applied Business Research, 28(6), 1183-1192.

13. Hernandez, G., \& Martinez-Solano, P. (2006). Banking relationships: Effects on debt terms for small Spanish firms. Journal of Small Business Management, 44(3), 315-333.

14. Horiuchi, T., Packer, F., \& Fukuda, S. (1988). What role has the 'main bank' played in Japan? Journal of Japanese and International Economies, 2(1), 159-180.

15. Kornai, J., Maskin, E. S., \& Roland, G. (2003). Understanding the soft budget constraint. Journal of Economic Literature, 41, 1095-1136.

16. Lehmann, E., \& Neuberger, D. (2001). Do lending relationships matter? Evidence from bank survey data in Germany. Journal of Economic Behaviour and Organization, 45(4), 339-359.

17. Ongena, S., \& Smith, D. (2001). The duration of bank relationships. Journal of Financial Economics, 61(3), 449-475.

18. Peltoniemi, J. (2007). The benefits of relationship banking: Evidence from small business financing in Finland. Journal of Financial Services Review, 31(1), 153-171.

19. Petersen, M., \& Rajan, R. (1995). The effect of credit market competition on lending relationships. Quarterly Journal of Economics, 110(2), 406-443.

\footnotetext{
${ }^{5}$ In terms of the average number of bank partnership.
} 
20. Sharpe, S.A. (1990). Asymmetric information, bank lending, and implicit contracts: A stylized model of customer relationships. Journal of Finance, 45, 1069-1087.

21. Sjögren, H. (1994). Long-term financial contracts in the bank-orientated financial systems. Scandinavian Journal of Management, 10(2), 315-330.

22. Von Thadden, E.L. (1995). Long-term contracts, short-term investment, and monitoring. Review of Economic Studies, 62(4), 557-575. 